\title{
KARAKTERISTIK PEMBAKARAN BRIKET CAMPURAN ARANG KAYU DAN JERAMI
}

\author{
Subroto \\ Jurusan Teknik Mesin Fakultas Teknik Universitas Muhammadiyah Surakarta \\ Jl.A.Yani Tromol Pos I Pabelan, Kartasura
}

\begin{abstract}
ABSTRAK
Dewasa ini, harga bahan bakar minyak semakin membumbung tinggi, sebagai alternatif maka dilakukan penelitian tentang potensi biomass jerami dan arang kayu sebagai sumber energi alternatif. Tujuan penelitian ini adalah mencampur jerami dan arang dengan komposisi tertentu dan menentukan karakter pembakarannya, sehingga nantinya dapat diketahui komposisi mana yang paling baik digunakan.

Dalam penelitian ini komposisi yang diuji adalah biobriket dengan perbandingan prosentase jerami: arang kayu $=30 \%: 70 \%, 40 \%: 60 \%, 50 \%: 50 \%$. Pengujian pembakaran dilakukan dengan kecepatan udara konstan untuk mengetahui besarnya laju pengurangan massa, laju pembakaran dan temperatur pembakaran, kemudian dilanjutkan dengan pengujian emisi polutan.

Berdasarkan percobaan dan parameter yang telah diuji, biobriket dengan campuran 50\% jerami dan 50\% arang kayu mempunyai laju pembakaran yang tinggi. Penambahan biomasa juga dapat menurunkan emisi polutan yang dihasilkan pada saat pembakaran. Komposisi biobriket terbaikyang dapat digunakan untuk kebutuhan sehari-hari adalah komposisi arang kayu : jerami $=50 \%: 50 \%$ karena lebih ramah lingkungan, sedangkan untuk kebutuhan industri, komposisi terbaik dengan pencapaian temperatur tertinggi adalah komposisi arang kayu : jerami $=70 \%: 30 \%$.
\end{abstract}

\section{Kata kunci : Biobriket, Arang Kayu dan Jerami, Karakteristik Pembakaran.}

\section{PENDAHULUAN}

Minyakbumi adalah energi yang tidak dapat diperbarui, tetapi dalam kehidupan sehari-hari bahan bakarminyakmasihmenjadipilihanutama sehingga akan mengakibatkan menipisnya cadangan minyak bumi di dalam bumi. Sementara batubara dan gas bumibelum dimaksimalkan pemanfaatannya untuk konsumsi dalam negeri. Sesungguhnya negara kita mempunyai potensi yang luar biasa mengenai sumber-sumber daya energi alternatif.

Beberapa energi alternatif yang biasa dikembangkan sebagai pengganti dari minyak bumi adalah gas bumi, batubara, arang kayu dan biomasa. Untuk gas bumi dan arang kayu masih merupakan energi yang masih belum dimaksi- malkan pemakaiannnya, berdasarkan hal diatas membuat peneliti berfikir untuk memanfaatkan sumber energi alternatif baru yang relatif murah, dan dapat dijangkau oleh masyarakat bawah.

Biomasa merupakan bahan hayati yang biasanya dianggap sebagai sampah dan sering dimusnahkan dengan cara dibakar. Biomassa tersebut dapat diolah menjadi biobriket, yang merupakan bahan bakar yang memiliki nilai kalor yang cukup tinggi dan dapat digunakan dalam kehidupan sehari-hari.

\section{BATASAN MASALAH}

Batasan masalah dalam penelitian ini dalah karakteristik pembakaran biobriket berbahan 
dasar arang kayu dengan campuran jerami dengan kecepatan udara pembakaran konstan dengan variasi komposisi.

\section{TUJUAN PENELITIAN}

Tujuan dari penelitian yang dilakukan ini untukmengetahuikarakteristikpembakaran biobriket campuran arang kayu dan jerami yang meliputi :

1. Untuk mengetahui pengaruh komposisi terhadap laju pembakaran.

2. Untuk mengetahui pengaruh komposisi terhadap temperatur pembakaran .

3. Untuk mengetahui pengaruh komposisi terhadap tingkat polusi hasil pembakaran.

\section{STUDI PUSTAKA}

Pembakaran biomasa akan dapat memperbaiki performa pembakaran dan mengontrol emisi NO- karena biomass banyak mengandung volatile matter termasuk juga jenis $\mathrm{N}$ volatile sebagai contoh $\mathrm{NH}_{3}$. Davidson et al, 1999 dalam (Himawanto, 2003).

Naruse etal (1999) melakukan penelitian mengenai karakteristik pembakaran biomasa yang berasal dari limbah jagung. Didapatkan bahwa karakteristik pembakaran biomasa tergantung dari komposisi biomasa, disamping itu juga didapatkan bahwa adapat memperbaiki proses penyalaan dari pembakaran batu bara, selain itu dalam pembakaran antara batubara dan biomas akan tercampur oleh abu dari batubara selama proses pembakaran.

Sudrajat (2000) melakukan penelitian tentang pemanfaatan energi dari biomasa sebagai sumber alternatif, dimana dia mendapatkan data yang menunjukkan besarnya tingkat sampah yang dihasilkan di beberapa kota besar di Indonesia pada tahun 2000 yang mana sebagian besarnya adalah sampah organik yang mempunyai nilai kalor yang cukup tinggi.

Antolin (1991) melakukan penelitian pembakaran limbah kopi, mendapatkan bahwa pembakaran limbah kopi menghasilkan kadar sulfur yang rendah, selain itu keringnya kandungan campuran awal dari limbah kopi akan menguntungkan karena naiknya nilai kalor, dan juga dari penelitian ini didapatkan satu kesimpulan bahwa pengeringan merupakan hal yang sangat penting dalam menyiapkan limbah kopi menjadi bahan bakar.

Biobriketmempunyai temperatur penyalaan (ignition temperature) yang lebih rendah dan burn out time yang lebih pendek dibandingkan dengan briket batubara. Ketika briket dipanasi temperaturnyanaik, setelahmencapai temperatur tertentu, volatile matter keluar dan terbakar disekitar briket. Temperatur ini disebut temperatur nyala. Temperatur nyala turun jika campuran biomasa lebih banyak (Naruse, 2001).

Huff et al 1998 dalam (Himawanto,2003) melakukan penelitian mengenai pengaruh ukuran, bentuk, densitas, kadar air dan temperatur dinding tungku terhadap waktu pembakaran kayu. Ukuran bahan bakar dan temperatur dinding tungku memberikan pengaruh besar terhadap waktu pembakaran. Kadar air memberikan pengaruh yang lebih kecil dan temperatur udara tidak memberikan pengaruh yang signifikan pada waktu pembakaran total.

\section{Pengertian Arang}

Menurut Ketaran (1980), arang adalah bahan padat yang berpori-pori dan merupakan hasil pembakaran dari bahan yang mengandung unsur C. Sebagian besar dari pori-porinya masih tertutup dengan hidrokarbon, dan senyawa organik lain yang komponennya terdiri dari “fixed carbon”, abu, air, nitrogen dan sulfur.

\section{Macam Arang}

Dalam bidang industri dikenal bermacammacam arang yang berhubungan dengan pembuatan dan kegunaannya. arang dihasilkan dari pembakaran bahan baku yang mengandung karbon. Bahan baku tersebut biasa berasal dari bahan nabati atau hasil ikutannya dan dari hasil hewani.

Carbon black adalah suatu karbon berbentuk amorf yang dihasilkan oleh pemanasan atau pemecahan oksidasi dari hidro karbon. Baked carbon adalah suatu istilah yang digunakan untuk arang yang dibuat dari pemanggangan pada suhu $1000-1800{ }^{\circ} \mathrm{C}$. Biasanya merupakan campuran dari bermacam-macam bahan yang mengandung karbon. 
Tahapan dalam pembakaran bahan bakar padat adalah sebagai berikut:

1. Pengeringan. Dalam proses ini bahan bakar mengalami proses kenaikan temperatur yang akan mengakibatkan menguapnya kadar air yang berada pada permukaan bahan bakar tersebut, sedangkan untuk kadar air yang berada didalam akan menguap melalui poripori bahan bakar tersebut.

2. Devolatilisasi. Yaitu proses bahan bakar mulai mengalami dekomposisi setelah terjadi pengeringan.

3. Pembakaran Arang. Sisa dari pirolisis adalah arang (fix carbon) dan sedikit abu, kemudian partikel bahan bakar mengalami tahapan oksidasi arang yang memerlukan 70\%-80\% dari total waktu pembakaran.

Faktor-faktor yang mempengaruhi pembakaran jerami dengan arang kayu antar lain:

a. Kadar air. Kandungan air yang tinggi menyulitkan penyalaan dan mengurangi temperatur pembakaran.

b. Kadar kalori. Semakin besar nilai kalor maka kecepatan pembakaran semakin meningkat.

c. Kadar abu. Kadar abu yang tinggi didalam jerami tidak mempengaruhi proses pembakaran. Kadar abu yang tinggi dalam jerami akan memepersulit penyalaan.

d. Volatile matter atau zat-zat yang mudah menguap. Semakin banyak kandungan volatile matter pada biobriket maka semakin mudah bio-briket untuk terbakar dan menyala.

e. Bulk density

Jerami mempunyai bulk density yang jauh lebih rendah dibandingkan arang kayu.

Secara teoritis pembakaran bahan bakar menghasilkan $\mathrm{CO}_{2}$ dan $\mathrm{H}_{2} \mathrm{O}$ saja, padahal kenyataannya pembakaran pada bahan bakar banyak yang tidak sempurna dimana akan menimbulkan zat-zat polutan yang berbahaya terhadap kesehatan manusia. Adapun beberapa polutan dari bahan bakar antara lain : Sulfur Dioksida $\left(\mathrm{SO}_{2}\right)$, Carbon Monoksida (CO), Oksida nitrogen $\left(\mathrm{NO}_{2}\right)$, Oksidan $\left(\mathrm{O}_{3}\right)$, Hidrokarbon (HC), Khlorin $\left(\mathrm{CL}_{2}\right)$, Partikel debu, Timah Hitam (Pb), Besi (Fe).

\section{METODOLOGI PENELITIAN} A. Diagram alir penelitian

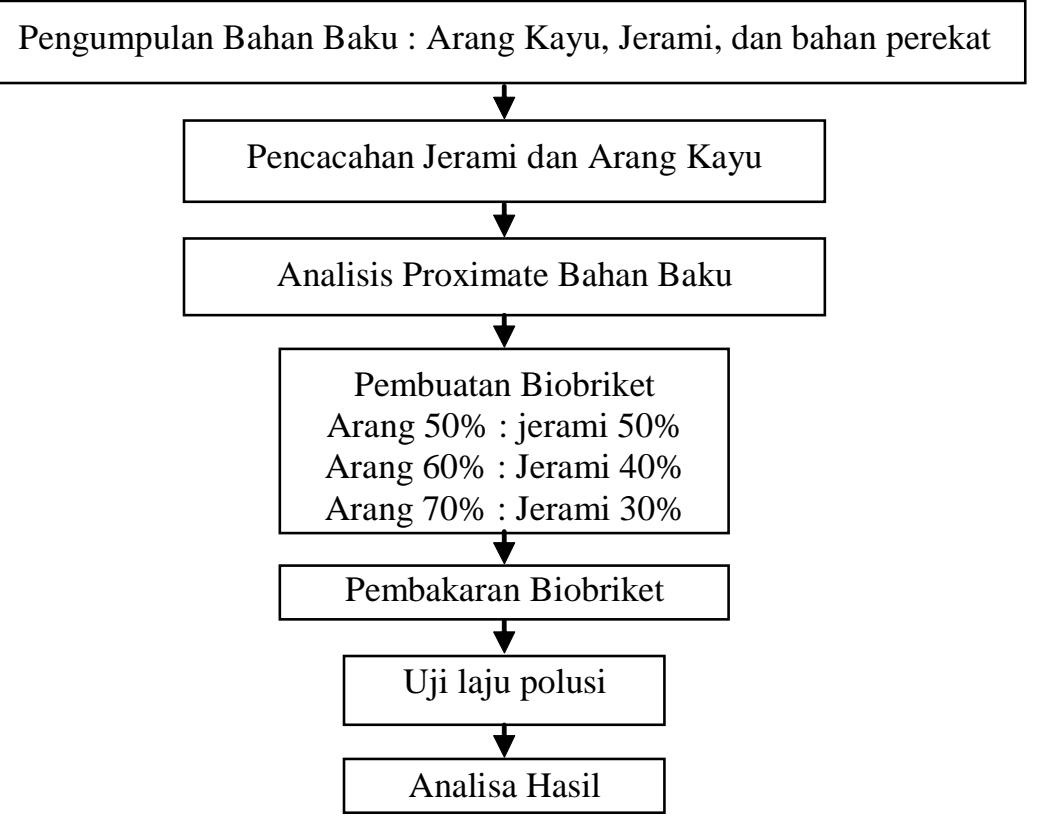

Gambar 1. Diaram Alir Penelitian 


\section{B. Pengolahan Bahan Baku}

1. Bahan Penelitian

a. Arang Kayu

b. Jerami

c. Bahan perekat tepung pati

d. Gas LPG, bahan bakar untuk memanaskan tungku

2. Pengolahan Bahan Baku

a. Penghalusan arang kayu menjadi serbuk.

c. Pencacahan jerami menjadi serbuk.

d. Pembuatan bahan perekat.

C. Pembuatan Biobriket

a. Pencampuran Bahan Baku

Arang kayu , jerami dan bahan perekat dicampurhingga rata dengan komposisi Jerami: Arang Kayu $=30 \%: 70 \%, 40 \%: 60 \%, 50 \%$ : $50 \%$ (dalam hal ini prosentase bahan perekat diabaikan dan dianggap homogen).

b. Pencetakan Biobriket

Bahan baku yang telah tercampur rata dimasukkan kedalam cetakan yang berbentuk silinder dengan diameter $1,5 \mathrm{~cm}$ dan tinggi $1,75 \mathrm{~cm}$.

c. Pengepresan

Bahan baku dimasukkan kedalam cetakan, kemudian dilakukan pengepresan dengan tekanan $100 \mathrm{~kg} / \mathrm{cm}^{2}$ dan didiamkan selama 10 menit. Setelah itu biobriket dikeluarkan dari cetakan dan dikeringkan ditempat yang tidak terkena sinar matahari secara langsung selama 3 hari.

Adapun Biobriket yang dihasilkan dapat dilihat pada gambar 2 .

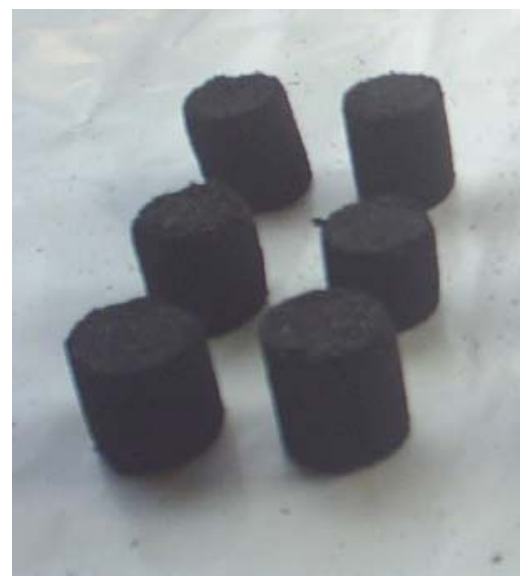

Gambar 2. Biobriket

\section{Peralatan Yang Digunakan}

Peralatan utama yang digunakan dalam penelitian ini terdapat di Laboratorium Teknik Mesin Universitas Muhammadiyah Surakarta

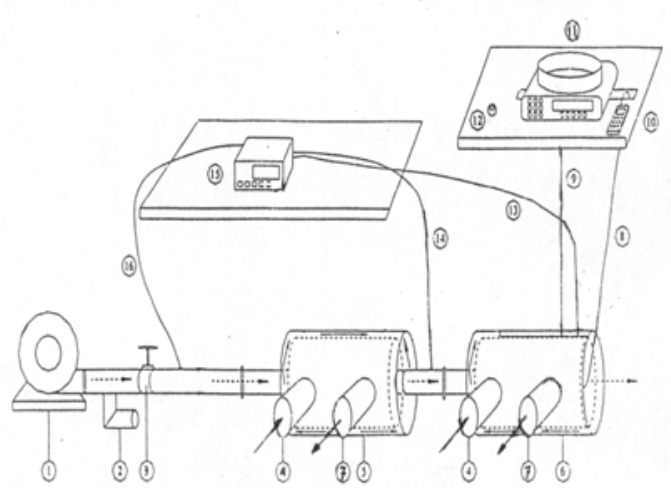

Gambar 3. Sketsa Alat Uji

Keterangan :

$\rightarrow$ Aliran pemanas LPG

Aliran udara

1. Blower

2. Saluran by pass

3. Katup pengatur aliran udara

4. Saluran masuk pemanas LPG

5. Tungku 1

6. Tungku 2

7. Saluran buang pemanas LPG

8. Termakopel temperatur dig

9. Kawat penggantung sampel bahan bakar

10. Digital termocouple reader

11. Electronic professional scale

12 Stop wacth

13. Termokopel temperatur gas pembakaran

14. Termokopel temperatur udara pre-heater

15. Digital termocouple reader

16. Termokopel temperatur udara 
HASIL DAN PEMBAHASAN

Sifat-sifat bahan dasar

Untuk mengetahui sifat-sifat bahan dasar dilakukan penelitian di Laboratorium Fakultas Kehutanan Universitas Gajah Mada.

Tabel 1. Sifat-sifat Bahan Dasar

\begin{tabular}{lcc}
\hline \multicolumn{1}{c}{ Sifat } & Jerami & Arang Kayu \\
\hline Kadar air (\%) & 12,47 & 6,86 \\
Kadar abu (\%) & 18,48 & 4,09 \\
Fix Karbon (\%) & 2,71 & 52,35 \\
Nilai kalor (kal/kg) & 3456,483 & 6987,723 \\
Volatile matter (\%) & 66,35 & 36,69 \\
\hline
\end{tabular}

Dari Tabel 1 dapat dilihat bahwa nilai volatile matter tertinggi dimiliki oleh jerami. Hasil diatas juga terungkap bahwa nilai kalor arang kayu dam jerami yang diteliti relatif masih cukup besar sehingga masih dapat dilakukan proses pembakaran. Kadar karbon tertinggi dimiliki oleh arang kayu dan terlihat untuk jerami memiliki kadar karbon yang lebih rendah, nilai kadar karbon ini akan memegang peranan penting dalam hal polusi udara yang ditimbulkan. Untuk kadar abu terrendah dimiliki oleh arang kayu karena sewaktu pembakaran hanya menghasilkan sedikit abu dibandingkan jerami, hal ini disebabbkan oleh nilai kadar air yang terkandung didalam jerami lebih tinggi dibandingkan dengan arang kayu.

\section{Gambar 5. Alat Pengepres Biobriket}

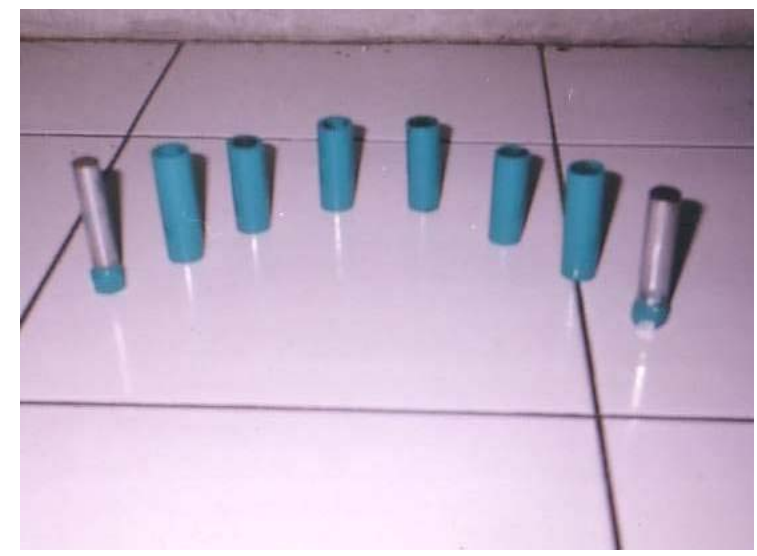

Gambar 6. Cetakan Biobriket

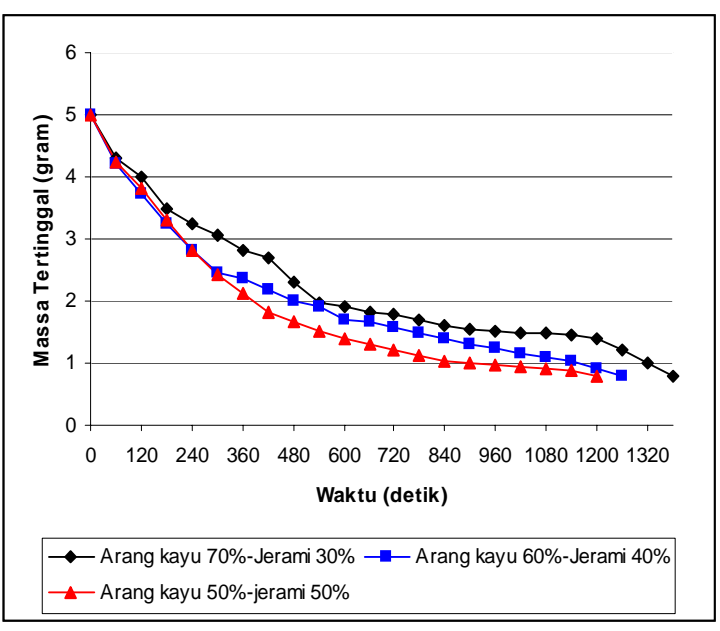

Gambar 1. Grafik MasaTertinggal terhadapWaktu 
pembakaran yang tinggi, sedangkan untuk temperatur pembakaran yang rendah terdapat pada biobriket dengan campuan $50 \%$ arang kayu dan 50\% jerami, hal tersebut disebabkan oleh besar kecilnya nilai kalor yang tedapat pada biobriket-biobriket tersebut.
3. Biobriket dengan tingkat polusi terendah adalah pada komposisi 50\% jerami : $50 \%$ arang kayu. Semakin banyak kandungan arang kayu pada biobriket maka semakin banyak kandungan HC, semakin banyak kandungan jerami pada biobriket akan menurunkan emisi polutan $\mathrm{HC}$

\section{DAFTAR PUSTAKA}

Antolin, G., Velasco,E., Irusta,R., Segovia,J.J.,1991, “ Combustion of Coffe Lignocellulose Waste “, Procendings of First Internasional Conference, Vilamoura, Portugal

Ketaran, S.G, 1980, “ Petunjuk Praktek Pengolahan Hasil Pertanian 3 “. Depdikbud. Jakarta

Himawanto, D.A, 2003, “Pengolahan Limbah Pertanian menjadi Biobriket sebagai salah satu Bahan Bakar Alternatif “, Laporan penelitian, UNS.

Naruse,I.,Gani,A.,Morishita,K.,2001,'Fundamental Characteristic on Co-Combustion of Low Rank Coal with Biomass',Pittsburg coal Conf

Sudradjat,R, 2001,'The Potensial of Biomass Energy Resources in Indonesia for the Possible Development of Clean Technology Process (CPT), Laporan penelitian, Jakarta 